\title{
Politicized Trade: What Drives Withdrawal of Trade Preferences?*
}

\author{
Martin Gassebner $^{\dagger} \quad$ Arevik Gnutzmann-Mkrtchyan ${ }^{\ddagger}$
}

November 17, 2017

\begin{abstract}
While it is well understood that industrialized countries use aid to grant political favors, little research covers alternative channels such as trade policy towards developing countries. We analyze eligibility investigations and revoking of U.S. Generalized System of Preferences (GSP) benefits to see whether political friends of the U.S. receive favorable treatment. While countries politically aligned with the U.S. are equally likely to be investigated, they are significantly less likely to have their benefits suspended.
\end{abstract}

Keywords: Trade Policy, Development, Generalized System of Preferences, United Nations General Assembly

JEL Classification: F13, F53, O19, O24

\footnotetext{
*We thank Richard Bluhm, Axel Dreher, Vera Eichenauer, Andreas Fuchs, Christoph Moser, and Maurizio Zanardi for helpful comments as well as Allison Carnegie and Shushanik Hakobyan for sharing their data. Conference participants at the European Trade Study Group 2016, Beyond Basic Questions 2016, European Public Choice Society 2017, and the Armenian Economic Association 2017 provided valuable feedback.

${ }^{\dagger}$ Corresponding author: University of Hannover, CESifo, KOF Swiss Economic Institute; gassebner@mak.uni-hannover.de

${ }^{\ddagger}$ University of Hannover, Belarusian Economic Research and Outreach Center (BEROC), CESifo; mkrtchyan@mak.uni-hannover.de
} 


\section{Introduction}

Strategic motives shape development policies (e.g., Dreher et al., 2009). Political friends - proxied by voting alignment in the United Nations General Assembly (UNGA) - are rewarded by the U.S. with increased aid flows or more lenient conditionality of concessional loans (e.g., Barro and Lee, 2005; Kilby, 2009; Dreher and Sturm, 2012).

We examine if a trade policy tool designed for fostering development is used strategically. We study this question using GSP country eligibility reviews regarding worker rights violations. GSP allows developed countries to offer unilateral preferential treatment of imports from developing countries (for an exhaustive overview, see Ornelas, 2016). The goal of this special provision is facilitating market access of developing countries' exports to foster their development. Preference-granting countries can decide on the list of goods and countries that qualify for the preferential access but the main criterion for eligibility should be the developing status of the exporter. $^{1}$

We analyze the GSP program of the U.S. that came into force in 1976. There are numerous exclusions on the country-product-pair level from preferential treatment. In particular, a country must not be communist, respect worker rights, recognize arbitral awards in favor of the U.S., and be "developing" (UNCTAD, 2016). The U.S. uses discretionary exclusions at the country-product level extensively, perceptibly affecting the GSP beneficiary (Blanchard and Hakobyan, 2015; Carnegie, 2015).

In order to be an effective strategic tool, GSP status must be valuable to the beneficiary countries. While the nationwide development impact is debated in the literature (e.g., Francois et al., 2006), it is documented that sectoral exports increase substantially (Hakobyan, 2013). Moreover, trade benefits attract U.S. multinationals to produce in the beneficiary country and ship their goods back to the U.S. (Blanchard and Matschke, 2015).

We focus on the U.S. for several reasons: first, U.S. GSP eligibility criteria allow for idiosyncratic application. For example, the status "developing country" is assigned without a specific income threshold, in contrast to the EU's GSP program which is based on income and exports (Hoekman and Ozden, 2005). Second, as

\footnotetext{
${ }^{1}$ See https://www.wto.org/english/tratop_e/devel_e/dev_special_differential_ provisions_e.htm.
} 
described above, the U.S. has been shown to use aid in a strategic manner. We provide robust and strong evidence that alignment with the U.S. results in a lower likelihood of GSP benefits removal.

\section{Hypothesis}

We want to assess whether aligned countries are rewarded with favorable GSP reviews. There are three distinct stages in the country review process for worker rights violations:

- Private entities (labor unions, firms, industry associations) can file petitions with the U.S. Trade Representative (USTR) outlining the alleged worker rights violations and requesting a review of preferences eligibility.

- The USTR decides annually which petitions are accepted and initiates investigations.

- The USTR decides whether the GSP status is revoked/suspended as a result of the investigation.

We do not expect the alignment with the U.S. to affect the likelihood of receiving a petition. $^{2}$

The USTR has discretion to accept or reject petitions. Conditional on accepting a petition and conducting an investigation countries can be suspended. If decisions have a strategic component, they might be affected by the alignment level.

Hypothesis: Political friends of the U.S. have a lower likelihood to:

1. be under investigation.

2. have their GSP beneficiary status suspended.

We test whether such favoritism is present and, if so, at which stage of the GSP review process.

\footnotetext{
${ }^{2}$ Using our empirical setup detailed below with petitions as the dependent variable confirms this (results available upon request).
} 


\section{Estimation Strategy}

We rely on probit models to analyze the investigation process of GSP eligibility due to worker rights violations. We apply the Mundlak approach to panel data with fixed effects for probit models as described in Wooldridge (2010). ${ }^{3}$ The underlying latent variable looks as follows:

$$
Y_{i t}^{*}=\alpha U N_{i, t-1}+\mathbf{X}_{i, t-1}^{\prime} \boldsymbol{\beta}+\gamma \overline{U N_{i}}+\overline{\mathbf{X}}_{i}^{\prime} \boldsymbol{\delta}+\lambda_{t}+\epsilon_{i, t},
$$

where $Y_{i t}^{*}$ stands for the investigation/suspension decision, $U N_{i, t-1}$ - UNGA voting alignment, $\mathbf{X}_{i, t-1}$ - the vector of controls, $\overline{U N_{i}}$ and $\overline{\mathbf{X}}_{i}$ - country averages (proxying country-fixed effects), $\lambda_{t}$ - time-fixed effects, $\epsilon_{i, t}$ - composite error term including random country-level effects. Subscript $i$ denotes GSP recipients. About $3 / 4$ of the UNGA votes take place in the fall. The USTR decides annually during the summer. Since current year values are not available at that time, we lag all explanatory variables by one year.

\section{Data}

Data on countries' GSP status, worker rights petitions, and investigations originate from the USTR (see Carnegie, 2015, who kindly shared this data). The dataset starts in 1985 when worker rights violations were added to the list of GSP eligibility criteria. In total 129 petitions about worker rights violations have been filed between 1985 and 2012. There are 243 country-year instances where benefits were suspended as a result of a review. ${ }^{4}$

UNGA voting alignment data come from Voeten et al. (2017). ${ }^{5}$ Total exports and exports under GSP are obtained from the U.S. International Trade Commission. Democracy is taken from the Polity IV Project, ${ }^{6}$ freedom from slave labor from Coppedge et al. (2015), and GDP and GDP per capita from Penn World Tables, version 7. We obtain the labor standards index from Mosley and Uno (2007) and

\footnotetext{
${ }^{3}$ Results are qualitatively similar using a linear probability model.

${ }^{4}$ Some suspensions were non-labor-driven. Our results are unaffected by their exclusion.

${ }^{5}$ We consider only country-years with at least 2 votes.

${ }^{6}$ http://www. systemicpeace.org/inscrdata.html
} 
the U.S. FDI stock in the recipient country from the OECD. ${ }^{7}$ Summary statistics are reported in Table A.1.

\section{Results}

Before turning to our econometric analysis, it is worthwhile looking at the average U.S. alignment in the UNGA of different groups of countries. We separate between countries which: (a) never have been; (b) those that currently are not but have been; and (c) those that currently are; investigated or suspended. As can be seen in Table 1, countries which are suspended in a given year had a significantly lower alignment with the U.S. in the year before. In all other cases the (mean) alignment is not statistically different from each other. So there seems to be no selection effect present, rather political friends appear to benefit. We turn to a more elaborate analysis below.

Tables 2 and 3 present marginal effects of probit estimations for the likelihood to be under investigation (columns $I 1-I 8$ ) and the likelihood of having GSP preferences suspended (columns $S 1-S 8$ ), respectively.

Our baseline regression ( $I 1$ and $S 1$ ) includes voting alignment as in Thacker (1999), calculating the share of common yes or no votes in total votes in a given year.

The labor rights index is available until 2002 only, it serves as a robustness test $(I 2, S 2)$. U.S. FDI could reduce the likelihood of GSP investigation or suspension (I3 and S3, again reducing the sample). The effect of the GSP revocation threat might depend on its economic importance. We control for this by including the value of GSP exports and share of exports under GSP in total exports (I4). As GSP exports of suspended countries are zero and prior GSP exports could be hindered by the investigation, we include total overall exports to the U.S. by the GSP recipient in regression $S 4$.

The alignment definition of Barro and Lee (2005) (BL) includes absences and abstention votes with alignment values of 0.5. This alternative is used in $I 5$ and $S 5$. Further, we measure alignment based solely on votes on key issues as identified by the U.S. Department of State $(I 6, S 6)$.

\footnotetext{
${ }^{7}$ http://stats . oecd.org/Index.aspx?DatasetCode=FDI_FLOW_INDUSTRY.
} 
Table 1: UNGA Voting Alignment with the U.S.

Country Groups

\begin{tabular}{|c|c|c|c|c|c|}
\hline Ever investigated & No & & \multicolumn{3}{|c|}{ Yes } \\
\hline Investigated in $t$ & & & $\mathrm{No}$ & & Yes \\
\hline Mean, t-1 & 0.24 & & 0.23 & & 0.21 \\
\hline Obs. & 2,218 & & 542 & & 121 \\
\hline Difference ( $t$-test) & & $\begin{array}{l}0.013 \\
(1.84)\end{array}$ & & $\begin{array}{l}0.019 \\
(1.57)\end{array}$ & \\
\hline Ever suspended & No & & & Yes & \\
\hline Suspended in $t$ & & & No & & Yes \\
\hline Mean, t-1 & 0.24 & & 0.23 & & 0.19 \\
\hline Obs. & 2,737 & & 275 & & 239 \\
\hline Difference ( $t$-test) & & $\begin{array}{l}0.010 \\
(1.05)\end{array}$ & & $\begin{array}{c}0.043^{* * *} \\
(4.05)\end{array}$ & \\
\hline
\end{tabular}

Next, we restrict the sample to countries that have been petitioned for GSP review at some point $(I 7, S 7)$. Columns $I 8$ and $S 8$ restrict the sample to countries that have been investigated at some point.

We do not see strong or consistent evidence of UNGA voting alignment on the decision to initiate or extend an ongoing investigation. But alignment reduces the likelihood of removal of preferences in all estimations. ${ }^{8}$ Moving from complete misalignment to full alignment decreases the probability of suspension by about $17-27 \%$ in the full sample, the reduction is $60 \%$ for countries that have been petitioned and up to $93 \%$ for countries that have been investigated. ${ }^{9}$ Our results are robust to a leave-one-out test for the countries which have been suspended.

The size of the economy increases investigation likelihood but doesn't have a consistent impact on suspensions. Higher GDP per capita, democracy level, and

\footnotetext{
${ }^{8} \mathrm{~A}$ significant interaction of freedom from slave labor and alignment indicates unequal judgment as a likely transmission channel (available upon request).

${ }^{9}$ The smaller effect of key vote is driven by its low time variation.
} 
Table 2: Impact of voting alignment on GSP investigation (marginal effects)

Dependent variable: Being investigated in $t$

\begin{tabular}{|c|c|c|c|c|c|c|c|c|}
\hline & I1 & $\mathrm{I} 2$ & I3 & I4 & I5 & I6 & I7 & I8 \\
\hline Alignment, t-1 & $\begin{array}{c}-0.01 \\
(-0.08)\end{array}$ & $\begin{array}{l}0.37^{*} \\
(2.52)\end{array}$ & $\begin{array}{c}0.04 \\
(0.37)\end{array}$ & $\begin{array}{c}-0.01 \\
(-0.08)\end{array}$ & & & $\begin{array}{c}0.02 \\
(0.08)\end{array}$ & $\begin{array}{c}-0.02 \\
(-0.06)\end{array}$ \\
\hline Alignment (BL), t-1 & & & & & $\begin{array}{c}0.04 \\
(0.41)\end{array}$ & & & \\
\hline Key votes, t-1 & & & & & & $\begin{array}{c}-0.01 \\
(-0.30)\end{array}$ & & \\
\hline GDP $(\log ), t-1$ & $\begin{array}{c}0.30^{* * *} \\
(3.53)\end{array}$ & $\begin{array}{c}0.29^{*} \\
(1.98)\end{array}$ & $\begin{array}{c}0.14 \\
(1.17)\end{array}$ & $\begin{array}{l}0.20^{*} \\
(2.01)\end{array}$ & $\begin{array}{c}0.30^{* * *} \\
(3.54)\end{array}$ & $\begin{array}{c}0.30^{* * *} \\
(3.52)\end{array}$ & $\begin{array}{c}0.80^{* * *} \\
(3.49)\end{array}$ & $\begin{array}{c}1.06^{* * *} \\
(3.51)\end{array}$ \\
\hline GDP p.c. $(\log ), t-1$ & $\begin{array}{c}-0.23^{* *} \\
(-3.13)\end{array}$ & $\begin{array}{c}-0.22 \\
(-1.64)\end{array}$ & $\begin{array}{c}-0.15 \\
(-1.32)\end{array}$ & $\begin{array}{l}-0.20^{*} \\
(-2.24)\end{array}$ & $\begin{array}{c}-0.23^{* * *} \\
(-3.13)\end{array}$ & $\begin{array}{c}-0.23^{* * *} \\
(-3.13)\end{array}$ & $\begin{array}{c}-0.63^{* *} \\
(-3.04)\end{array}$ & $\begin{array}{l}-0.8^{* *} \\
(-2.95)\end{array}$ \\
\hline Democracy, t-1 & $\begin{array}{c}-0.01^{* * *} \\
(-3.18)\end{array}$ & $\begin{array}{c}-0.01^{* *} \\
(-2.58)\end{array}$ & $\begin{array}{c}-1.40 \mathrm{E}-3 \\
(-0.72)\end{array}$ & $\begin{array}{c}-2.08 \mathrm{E}-3 \\
(-1.51)\end{array}$ & $\begin{array}{c}-4.57 \mathrm{E}-3^{* *} \\
(-3.17)\end{array}$ & $\begin{array}{c}-4.48 \mathrm{E}-3^{* *} \\
(-3.14)\end{array}$ & $\begin{array}{c}-0.01^{* * *} \\
(-3.63)\end{array}$ & $\begin{array}{c}-0.02^{* * *} \\
(-3.49)\end{array}$ \\
\hline No-slave labor, t-1 & $\begin{array}{l}-0.14^{*} \\
(-1.99)\end{array}$ & $\begin{array}{c}-0.70^{* * *} \\
(-4.54)\end{array}$ & $\begin{array}{l}-0.37^{*} \\
(-2.47)\end{array}$ & $\begin{array}{l}-0.10 \\
(-1.23)\end{array}$ & $\begin{array}{l}-0.14^{*} \\
(-2.02)\end{array}$ & $\begin{array}{c}-0.13 \\
(-1.94)\end{array}$ & $\begin{array}{l}-0.38^{*} \\
(-1.96)\end{array}$ & $\begin{array}{c}-0.42 \\
(-1.59)\end{array}$ \\
\hline Labor rights, t- 1 & & $\begin{array}{c}-3.71 \mathrm{E}-3^{* *} \\
(-3.15)\end{array}$ & & & & & & \\
\hline FDI $(\log ), t-1$ & & & $\begin{array}{c}-0.01 \\
(-1.43)\end{array}$ & & & & & \\
\hline GSP value $(\log ), \mathrm{t}-1$ & & & & $\begin{array}{l}0.01^{*} \\
(2.09)\end{array}$ & & & & \\
\hline GSP share, t-1 & & & & $\begin{array}{l}-0.11^{*} \\
(-2.00)\end{array}$ & & & & \\
\hline Countries & 121 & 92 & 107 & 118 & 121 & 121 & 44 & 32 \\
\hline Observations & 2,207 & 1,360 & 960 & 1,727 & 2,208 & 2,200 & 758 & 550 \\
\hline
\end{tabular}

$\mathrm{t}$ statistics in parentheses

${ }^{*} p<0.05,{ }^{* *} p<0.01,{ }^{* * *} p<0.001$ 
Table 3: Impact of voting alignment on GSP benefits removal (marginal effects)

Dependent variable: Being suspended in $t$

\begin{tabular}{|c|c|c|c|c|c|c|c|c|}
\hline & S1 & $\mathrm{S} 2$ & S3 & $\mathrm{S} 4$ & S5 & S6 & S7 & S8 \\
\hline Alignment, t-1 & $\begin{array}{c}-0.22^{* * *} \\
(-4.42)\end{array}$ & $\begin{array}{c}-0.22^{* * *} \\
(-3.34)\end{array}$ & $\begin{array}{c}-0.17^{* * *} \\
(-3.83)\end{array}$ & $\begin{array}{c}-0.27^{* * *} \\
(-4.35)\end{array}$ & & & $\begin{array}{c}-0.60^{* * *} \\
(-3.74)\end{array}$ & $\begin{array}{c}-0.93^{* * *} \\
(-4.00)\end{array}$ \\
\hline Alignment (BL), t-1 & & & & & $\begin{array}{c}-0.24^{* * *} \\
(-4.18)\end{array}$ & & & \\
\hline Key votes, t-1 & & & & & & $\begin{array}{l}-0.05^{*} \\
(-2.32)\end{array}$ & & \\
\hline GDP (log), t-1 & $\begin{array}{l}-0.08^{*} \\
(-2.27)\end{array}$ & $\begin{array}{c}-0.13 \\
(-1.75)\end{array}$ & $\begin{array}{c}-0.03 \\
(-0.73)\end{array}$ & $\begin{array}{l}-0.03 \\
(-0.52)\end{array}$ & $\begin{array}{l}-0.08^{*} \\
(-2.25)\end{array}$ & $\begin{array}{c}-0.07 \\
(-1.72)\end{array}$ & $\begin{array}{c}0.03 \\
(0.44)\end{array}$ & $\begin{array}{c}0.18 \\
(1.63)\end{array}$ \\
\hline GDP p.c. $(\log ), t-1$ & $\begin{array}{c}0.08^{*} \\
(2.29)\end{array}$ & $\begin{array}{c}0.11 \\
(1.57)\end{array}$ & $\begin{array}{c}-0.06 \\
(-1.14)\end{array}$ & $\begin{array}{c}0.08 \\
(1.62)\end{array}$ & $\begin{array}{l}0.08^{*} \\
(2.31)\end{array}$ & $\begin{array}{l}0.07 \\
(1.8)\end{array}$ & $\begin{array}{c}-0.02 \\
(-0.20)\end{array}$ & $\begin{array}{c}-0.17 \\
(-1.52)\end{array}$ \\
\hline Democracy, t-1 & $\begin{array}{c}-0.01^{* * *} \\
(-5.69)\end{array}$ & $\begin{array}{c}-0.01^{* * *} \\
(-5.38)\end{array}$ & $\begin{array}{c}-9.27 \mathrm{E}-4 \\
(-1.04)\end{array}$ & $\begin{array}{c}-3.17 \mathrm{E}-3^{* *} \\
(-3.08)\end{array}$ & $\begin{array}{c}-0.01^{* * *} \\
(-5.80)\end{array}$ & $\begin{array}{c}-0.01^{* * *} \\
(-5.55)\end{array}$ & $\begin{array}{c}-0.01^{* * *} \\
(-4.77)\end{array}$ & $\begin{array}{c}-0.01^{* * *} \\
(-4.76)\end{array}$ \\
\hline No-slave labor, t-1 & $\begin{array}{c}-0.03 \\
(-0.70)\end{array}$ & $\begin{array}{l}-0.17^{*} \\
(-2.04)\end{array}$ & $\begin{array}{c}-0.30^{* * *} \\
(-4.5)\end{array}$ & $\begin{array}{c}-0.04 \\
(-0.52)\end{array}$ & $\begin{array}{c}-0.04 \\
(-0.89)\end{array}$ & $\begin{array}{c}-0.07 \\
(-1.46)\end{array}$ & $\begin{array}{c}-0.17 \\
(-1.37)\end{array}$ & $\begin{array}{c}-0.13 \\
(-0.83)\end{array}$ \\
\hline Labor rights, t-1 & & $\begin{array}{c}6.94 \mathrm{E}-5 \\
(0.10)\end{array}$ & & & & & & \\
\hline FDI $(\log ), \mathrm{t}-1$ & & & $\begin{array}{l}-0.01^{*} \\
(-2.44)\end{array}$ & & & & & \\
\hline Trade (log), t-1 & & & & $\begin{array}{c}1.59 \mathrm{E}-3 \\
(0.37)\end{array}$ & & & & \\
\hline Countries & 122 & 93 & 111 & 122 & 122 & 122 & 44 & 32 \\
\hline Observations & 2,485 & 1,484 & 1,283 & 2,128 & 2,486 & 2,478 & 890 & 677 \\
\hline
\end{tabular}

$\mathrm{t}$ statistics in parentheses

${ }^{*} p<0.05,{ }^{* *} p<0.01,{ }^{* * *} p<0.001$ 
to some extent freedom from slave labor reduce the likelihood of investigations and suspensions. Higher shares of GSP exports in total exports and respect for labor rights only reduce the likelihood to be investigated.

\section{Conclusions}

This paper analyzes cases of eligibility investigations and revoking of U.S. GSP benefits to see whether political friends of the U.S. receive favorable treatment. Countries politically aligned with the U.S. are significantly less likely to have their benefits suspended. There is, however, no effect on the likelihood to be investigated. This is evident, e.g., in 1992: Syria (GSP suspended) vs Guatemala and El Salvador (investigated without suspension) - UNGA alignment 0.132 vs 0.241 and 0.280; freedom from slave labor 0.792 vs. 0.410 and 0.457, respectively. Swaziland (as nondemocratic as Syria) was investigated but not suspended in 1996 (UNGA alignment 0.404; freedom from slave labor 0.375). 


\section{References}

Barro, R. J., Lee, J.-W., 2005. IMF programs: Who is chosen and what are the effects? Journal of Monetary Economics 52 (7), 1245-1269.

Blanchard, E., Hakobyan, S., 2015. The US Generalised System of Preferences in principle and practice. World Economy 38 (3), 399-424.

Blanchard, E., Matschke, X., 2015. US multinationals and preferential market access. Review of Economics and Statistics 97 (4), 839-854.

Carnegie, A., 2015. Power plays: How international institutions reshape coercive diplomacy. Cambridge University Press.

Coppedge, M., Gerring, J., Lindberg, S. I., Teorell, J., Altman, D., Bernhard, M., Fish, M. S., Glynn, A., Hicken, A., Knutsen, C. H., et al., 2015. Varieties of democracy: Codebook v4. Varieties of Democracy (V-Dem) Project.

Dreher, A., Sturm, J.-E., 2012. Do the IMF and the World Bank influence voting in the UN General Assembly? Public Choice 151 (1), 363-397.

Dreher, A., Sturm, J.-E., Vreeland, J. R., 2009. Global horse trading: IMF loans for votes in the United Nations Security Council. European Economic Review 53 (7), $742-757$.

Francois, J., Hoekman, B., Manchin, M., 2006. Preference erosion and multilateral trade liberalization. World Bank Economic Review 20 (2), 197-216.

Hakobyan, S., 2013. GSP expiration and declining exports from developing countries. Fordham University, mimeo.

Hoekman, B., Ozden, C., 2005. Trade preferences and differential treatment of developing countries: A selective survey. World Bank Policy Research Working Paper (3566).

Kilby, C., 2009. The political economy of conditionality: An empirical analysis of World Bank loan disbursements. Journal of Development Economics 89 (1), 51-61. 
Mosley, L., Uno, S., 2007. Racing to the bottom or climbing to the top? Economic globalization and collective labor rights. Comparative Political Studies 40 (8), 923-948.

Ornelas, E., 2016. Special and differential treatment for developing countries. Handbook of Commercial Policy 1, 369-432.

Thacker, S. C., 1999. The high politics of IMF lending. World Politics 52 (1), 38-75.

UNCTAD, 2016. GSP - Handbook on the scheme of the United States of America.

Voeten, E., Strezhnev, A., Bailey, M., 2017. United Nations General Assembly voting data, version 12. http://hdl. handle.net/1902.1/12379.

Wooldridge, J. M., 2010. Econometric analysis of cross section and panel data. MIT Press. 


\section{A Summary statistics}

Table A.1: Sample summary statistics

$\begin{array}{lrrrrr} & \text { Obs. } & \text { Mean } & \text { S.D. } & \text { Min } & \text { Max } \\ \text { Suspended } & 3,283 & 0.07 & 0.26 & 0.00 & 1.00 \\ \text { Investigated } & 3,282 & 0.05 & 0.21 & 0.00 & 1.00 \\ & & & & & \\ \text { Alignment } & 3,252 & 0.23 & 0.14 & 0.00 & 1.00 \\ \text { Alignment (BL) } & 3,252 & 0.30 & 0.11 & 0.00 & 0.84 \\ \text { Key votes } & 3,259 & 0.42 & 0.25 & 0.00 & 1.00 \\ \text { GDP (log) } & 2,988 & 16.45 & 1.93 & 11.75 & 22.13 \\ \text { GDP p.c. (log) } & 2,988 & 7.97 & 1.07 & 5.18 & 10.98 \\ \text { Democracy } & 2,792 & 1.84 & 6.42 & -10.00 & 10.00 \\ \text { No-slave labor } & 2,928 & 0.67 & 0.20 & 0.03 & 0.94 \\ \text { Labor rights } & 1,824 & 24.11 & 7.91 & 0.00 & 34.50 \\ \text { FDI (log) } & 1,652 & 18.81 & 2.81 & 13.82 & 25.10 \\ \text { Trade (log) } & 2,823 & 18.33 & 2.96 & 6.05 & 24.64 \\ \text { GSP value (log) } & 2,427 & 15.35 & 3.43 & 6.26 & 22.74 \\ \text { GSP share } & 2,735 & 0.11 & 0.17 & 0.00 & 0.98\end{array}$

Note: The summary statistics are based on the sample of GSP beneficiaries and suspended countries with at least two UNGA votes in a given year. 